\title{
Why do Firms Live Longer than Others? The Elixir of (Eternal) Life of Blue Chip American Companies
}

\author{
Pedro M. Nogueira Reis ${ }^{1}$ \\ ${ }^{1}$ Assistant professor, Polytecnic Institute, School of Technology and Management of Viseu, Portugal \\ Correspondence: Pedro M. Nogueira Reis, assistant professor, Polytecnic Institute, School of Technology and \\ Management of Viseu, Portugal.
}

Received: December 6, 2017

Accepted: December 26, $2017 \quad$ Online Published: January 3, 2018

doi:10.5430/ijba.v9n1p64

URL: https://doi.org/10.5430/ijba.v9n1p64

\begin{abstract}
Purpose: Why do certain companies live longer than others? The average lifespan of a listed north and South American company is over 33 years and in Europe the average age of a company is 52 (Note 1). In 1288, Stora Enso a big pulp and paper company from Sweden issued its first share. According to credit rating agency Tokyo Shoko Research, in Japan, there are more than 20,000 companies with more than 100 years' old. Through a sample of blue ship American listed oldest companies and quarter panel data from 1988-2013 this article identifies more than 8 significant explanatory variables and ascertains relevant factors related with longevity.

Methodology: A new robust standard errors for panel regressions with cross-sectional dependence based on Driscoll-Kraay estimator is applied. This method (stata xtscc) is heteroskedasticity consistent and the standard error estimates are robust to general forms of cross-sectional and temporal dependence surpassing the deficiencies of traditional panel data statistical approaches.

Findings: The sample of blue ship companies and panel regressions with Driscoll-Kraay estimator shows that the most relevant factors to induce longevity are related with growth opportunities perspective and horizon, cash liquidity, profitability and shareholders remuneration whether from dividends or repurchases, capital structure, strong claims-compliance-liability structure department, innovation and firm size.

Originality: This paper's topic considers for the first-time age as a dependent variable and not a control one. Also, the large time period of study, including quarterly observations is new, as well as the original approach to estimation applied to this theme, considered as an alternative to traditional panel data methods.

Practical implications: With these determinants identified, professionals and academics can use them as benchmarking and a recipe to endure and assuring bigger lifespan for other mature and young companies.
\end{abstract}

Keywords: company life, firm life, lifespan, age, endure

\section{Introduction}

In 1288, Stora Enso a big pulp and paper company from Sweden issued its first share. According to credit rating agency Tokyo Shoko Research, in Japan, there are more than 20,000 companies with more than 100 years old, which 5 of them are more than 1,000 years old. The list includes Nissiyama Onsen Keiunkan, a hotel founded in 705, which is supposed to be the oldest company in the world (Note 2). Japan has a huge number of ancient companies: of the fifty companies worldwide founded before the year 1300 that are still operating, 24 are Japanese (Note 3). If you want to find the reasons for a long and healthy life of humans, you will try to find the grounds in an ancient instead of a young one. You will try to see if genetics, food, atmosphere, stress, cultural, social, work or other environments have anything to do with a long lifespan. The same approach is applied in this paper when studying several benchmark old listed companies in USA.

Firm age appears as a prolific field of research today in most relevant journals (Coad et al., (2017). Age has been used as a variable to explain performance (Van Stel et al. 2017), survival (Carr, Haggard, Hmieleski, \& Zahra, 2010, Reis \& Augusto 2014b), firm risk taking (Chrisman \& Patel, 2012; Desai, 2008), growth (Ahlstrom, Young, Chan, \& Bruton, 2004), experience (Desai, 2008), valuation (Reis \&Augusto $(2013,2014)$ and more recently in the influence of international entry modes choice (Xie, 2017). There is a lack of studies that cover the reasons explaining company life. The nearest studies approaching this matter are the ones related with firm survival, but even those don't reach 
any conclusion about the chances of reaching a young or a mature state, or why do certain firms live longer than others appearing to have found the elixir of (eternal) life. Basically they study the reasons associated with delisting.

Our study aims to contribute to this new approach on firm age. This paper gathered a sample of benchmark older companies in USA and study their behavior since 1988-2017 and using panel data approach modified Regression with Driscoll-Kraay estimator This paper finds specific significant variables that would allow to understand in a more detailed way which are the control and explanatory variables causing extended firm life.

\section{Literature Review}

Younger firms have resource disadvantages, lack of experience and, less external networks which can lead them to have weaker abilities to deal with risks and thus a higher failure rate (Ahlstrom, Bruton, \& Yeh, 2008). Older firms have resources advantages (more organization and accumulated assets and even non-core assets) which can take them to take more risks and hence reduce their default rate (Hannan \& Freeman, 1984; Stinchcombe, 1965). Xie (2017) considering the work of Autio, et al. (2000); Cyert \& March (1963); Autio et al. (2000); Barron et al. (1994); Levinthal \& March (1993) suggests that younger firms have stronger learning advantages acquiring new knowledge more rapidly and firmly increasing their adaptability changes in environmental and therefore reduce their failure rate. Conversely, older firms may have learning disadvantages because more resources and fierce capabilities can lead to "competence traps", which can reduce their learning and knowledge and that's why older firms will develop more inertial, and less reactive to external changes leading to a higher default rate. Loderer et al. (2017) indicates the decline in growth opportunities (proxied by Tobin's q) occurring with the ageing of firms due to the organizational inflexibility in sequence of a focus on improving the management of the assets.

Yang and Aldrich (2017) reexamine the concept of liability of newness studying the resources at birth and resources collected immediately after the entrance in market. Amongst the studies over age and R\&D, Rafiq et al. (2016) conclude that mature $R \& D$ active firm earns more profit and generates more sales than a younger non-innovative firm. The turning point at which $R \& D$ activities switch from a negative to positive influence profit and sales is 37 years and 22 years, respectively. Their results are consistent with the liability of newness, meaning that company investment in R\&D takes time to impact on financial performance. They use firm age as a moderator of R\&D's impact on knowledge creation. Coad et al. (2016) explore the relationship between innovation and firm growth for firms of different ages showing that young firms face larger performance benefits from R\&D at the upper quantiles of the growth rate distribution, but face larger decline at the lower quantiles. They also conclude that R\&D investment by young firms appears to be significantly riskier than R\&D investment made by mature firms. Considering growth rates, the authors found a negative relationship between firm age and growth rates (sales, productivity and employment), with older age groups having lower growth rates.

Wöhrl et al. (2009) reach a conclusion that firm age is a moderating factor influencing whether technology investments lead to higher growth or profitability in the life cycle of technology-based growth companies. Their findings reinforce their proposition that firm age might cause significant differences in the relationship between R\&D investments and success of technology-based growth companies. The conclusion is testified by the works over firm life cycle theories (Churchill \& Lewis, 1983; Kazanjian, 1988).

Cowling et al. (2017) confirms the well-established, and negative, firm age-growth relationship according life cycle theory. They also found that entrepreneurial experience did not have any substantive effects on small business performance. Cowling et al. (2017) states that firm growth should be negatively associated with age.

Studies like Coad et al. (2013) and Haltiwanger et al. (2013) defend that firm age should be included as a separate variable when examining firm performance and not related with firm size. Young business is more liked to be concerned with survival in the first few years of age (Cowling 2006, Reis e Augusto, 2014b). That's why growth should be observed in mature businesses after passing the liability of youth (Audretsch and Mahmood 1994; Watson 2012 and Reis e Augusto, 2013).

On the other hand, older firms suffer from 'liabilities of age', due to lower commitment and involvement compared to young firms (Churchill and Lewis 1983). Performance usually has a negative relation with the firm age, see Nunes et al. (2013) and Reis e Augusto (2013) works. Conversely, as both the firm and entrepreneurs become more aged and thus experienced, Cowling et al. (2017) indicate as example the work of Vassilakis (2008), as a confirmation for the positive relation between performance and age.

On the relationship between valuation and age, Reis e Augusto (2013) study the relation amongst Terminal Value and performance and age whereas they conclude that the life expectancy of a company is not infinite; the age should be an important variable to consider in the average life expectancy at the time of analysis with a view to determining the 
value of the company and they found a negative relation between terminal value and age. They also argue that it was also important to consider the state in which that company is during its life cycle, as well as its capacity for regeneration. Studies relating age and valuation, Reis \& Augusto (2014a) argue that as age advances, the average life expectancy reduces, a stage of maturity is surpassed and anticipation for the period of decline or extinction should be considered in valuation models. Reis \& Augusto (2014) study a real case from companies' creation to their demise, pushing knowledge forward by providing a consistent life and mortality expectancy table for each age of the company, presenting valuation models with an explicitly and different survival rate for each year.

The risk and influence of age on risk is considered by Hasan and Habib (2017) revealing that the roles of both cash flow volatility and information uncertainty in affecting idiosyncratic volatility fluctuate depending on firm life cycle stages. They state that prior studies use firm age as a life cycle proxy showing that idiosyncratic volatility is lower for older firms like the works of (Fink et al., 2010; Gaspar \& Massa, 2006). On the opposite side, other studies find a positive relation between age and idiosyncratic volatility (Luo \& Bhattacharya, 2009; Ferreira \& Laux, 2007), whereas others like (Tan \& Liu, 2016) finds no association between them. Hasan and Habib (2017) argue that this mixed evidence relates to the use of firm age as a proxy for life cycle. The authors use the Dickinson (2011) five-stage life cycle model. Hasan and Habib (2017) document that, idiosyncratic volatility is higher for the introduction and decline stages of the firm life cycle, while it is lower for the growth and maturity stages. They show that the role of cash flow volatility in affecting idiosyncratic volatility attenuates during the growth and mature stages.

Other studies focused on the relation of firm age and innovation (Pellegrino 2017; Cucculelli 2017), age and financial performance (Van Stel et al. 2017), age and export capacity (Grazzi and Moschella 2017), and age on survival rate (Anyadike-Danes and Hart 2017, Reis e Augusto 2014b)) and age on growth (Cowling et al. 2017).

Coad et al. (2017) says that the dominant vision today is that each type of firm co-exists and contributes to economic growth in a different way, through product and/or process innovation. They state that firm age is more than a control variable, and the opposition between young and old firms deserves reconsideration. According to the authors, age will open new windows of research opportunity in the field of diversification, and in topics like integration and specialization in horizontally or vertically-related industries, moderated with age.

I must underline that the company age isn't used as a dependent variable and studies related with the with the study of the causes of the lifespan of a company don't exist. Coad (2010) suggests that the firm age distribution of the population of firms is approximately exponential, implying that the modal age should be situated in the lowest age category, and the number of firms decreasing as age increases. Coad et al. (2017) argue that the study over company age is undeniably still far from reaching a maturity and theoretical concepts related to age are still being refined. Coad et al. (2017) defends that firm performance does not influence age, because age cannot be influenced. The opinion of the author is different because the duration of a company, as the duration of a human life can be for certain influenced by certain factors. Please see all the studies about firm survival. All of the academic papers covering this special issue indirectly study the lifespan of a company. External, internal factors for sure have a specific influence and causality on firm's life expectancy as Reis \& Augusto (2012) and Reis \& Augusto 2014b) defend. But Coad et al. (2017), refers the study of Loderer et al.(2017), where the authors defend a "Reverse causality" between age and performance showing an opposite view over performance influencing age.

For instance, Chen (2011) defends that the reason the book-to-market effect is stronger in small stocks is because smaller stocks generally have shorter life expectancy and consequently smaller equity duration. He built a model in which the book-to-market effect is stronger in stocks with shorter life expectancy. He used the exit of listing probability as a proxy for life expectancy.

\section{Methodology, Sample and Data}

There is a common utilization in academic works of age as a control or explanatory variable, per classes or logarithmic. Xie (2017), Chen (2011) use firm age as log of firm age as control/ explanatory variable, whereas Rafiq et al. (2016), Code et al. (2016) use the number of years of operation as a proxy for firm age. Yang and Aldrich (2017) Hasan and Habib (2017) and Wöhrl et al. (2009) use company age as a moderator/explanatory variable. Cowling et al. (2017) use firm age and business age as explanatory variables.

I gathered 1534 quarter observations from 03/31/88 to 06/30/2017 for 13 old companies and for 21 variables in different industries forming a panel data, obtained in www.globalfinancialdata.com. 
Table 1. List of companies in database

\begin{tabular}{llll}
\hline Company & Code & $\begin{array}{l}\text { Data of } \mathbf{1}^{\text {st }} \text { quote in } \\
\text { avaialable database }\end{array}$ & Firm age (years) \\
\hline American Express & AXP & $13 / 10 / 1866$ & 150,789 \\
Apple & AAPL & $12 / 12 / 1980$ & 36,5726 \\
E.I. du Pont de Nemours \& Co. & DD2 & $30 / 10 / 1915$ & 101,737 \\
McDonald's Corp. & MCD & $30 / 04 / 1965$ & 52,20274 \\
Merck \& Co & MRK & $31 / 12 / 1934$ & 82,55342 \\
3M Company & MMM & $31 / 03 / 1931$ & 86,30959 \\
Walt Disney Co. (The) & DIS & $31 / 01 / 1946$ & 71,46027 \\
Caterpillar Inc. & CAT & $27 / 02 / 1927$ & 90,4 \\
Chevron Corp. (Standard Oil of California) & CVX & $29 / 02 / 1912$ & 105,4055 \\
International Business Machines Corp & IBM & $31 / 08 / 1911$ & 105,9041 \\
Coca Cola Co. & KO & $29 / 08 / 1919$ & 97,90411 \\
Microsoft Corp. & MSFT & $13 / 03 / 1986$ & 31,32055 \\
United Technologies Corp. & UTX & $30 / 11 / 1928$ & 88,6411 \\
\hline
\end{tabular}

From a list of 21 (Note 4) variables we built up 8 relevant variables, avoiding multicollinearity, plus the dependent variable. The final set of variables is the one presented in Table 2.

Table 2. List of 9 variables used in modeling

\begin{tabular}{|c|c|c|}
\hline Variables & Description & Measure \\
\hline Company_Age_days & $\begin{array}{l}\mathrm{N}^{\mathrm{o}} \text { of days from the first available quote to } \\
06 / 30 / 2017 \text { (days) }\end{array}$ & Age, company life \\
\hline PERatioBasic & $\begin{array}{l}\text { Price earnings ratio (share price USD/ net } \\
\text { earnings last } 12 \text { months USD) }\end{array}$ & Performance measure, growth opportunities \\
\hline researchoverassets & $\begin{array}{l}\text { Research expenses (Million USD)/Total } \\
\text { assets (Million USD) }\end{array}$ & $\begin{array}{l}\text { R\&D intensity. Innovation, ability to produce } \\
\text { abnormal results }\end{array}$ \\
\hline NetSalesOrRevenues & Net sales and services renderes & Size \\
\hline Payout & $\begin{array}{l}\text { Dividends per share (USD)/EPS before } \\
\text { non-recurring items (USD) }\end{array}$ & $\begin{array}{l}\text { Pay-out, shareholders remuneration, over } \\
\text { recurring profits }\end{array}$ \\
\hline SellingGeneralAdministrativ & $\begin{array}{l}\text { Selling and administrative expenses } \\
\text { (Million USD) }\end{array}$ & $\begin{array}{l}\text { Fixed, structure costs, ability com cope with } \\
\text { litigation, internal auditing and compliance, } \\
\text { risk management and liability control }\end{array}$ \\
\hline Cashassets & $\begin{array}{l}\text { Cash and cash equivalents at the final of } \\
\text { period (Million USD)/Total assets (Million } \\
\text { USD) }\end{array}$ & $\begin{array}{l}\text { Liquidity, financial strength, ability to invest } \\
\text { and to resist to cycle downturns }\end{array}$ \\
\hline IssuancePurchaseOfEquitySh & $\begin{array}{l}\text { Issuance or purchase of equity shares } \\
\text { (Million USD) }\end{array}$ & $\begin{array}{l}\text { If issuance the signal is positive and share } \\
\text { buybacks is negative. Measures Pay-out, } \\
\text { shareholders remuneration, Market share } \\
\text { liquidity, free float, capital needs. }\end{array}$ \\
\hline DebtPPP & $\begin{array}{l}\text { Long term debt (Million USD)/Net property } \\
\text { plant and equipment (Million USD) }\end{array}$ & $\begin{array}{l}\text { Debt structure, financial stability in the long } \\
\text { term, financial equilibrium. }\end{array}$ \\
\hline
\end{tabular}

The model to be tested is to check if those variables are determinants of the life of a company is:

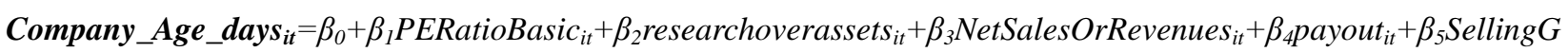
eneralAdministrativ $_{i t}+\beta_{6}$ Cashasset $_{i t}+\beta_{7}$ IssuancePurchaseOfEquitySh $_{i t}+\beta 8 D$ DebtPPP ${ }_{i t}+\xi_{i t}$

With $\mathrm{i}=1, \ldots, \mathrm{N}$ companies and $\mathrm{t}=1, \ldots, \mathrm{T}$ quarter periods $\quad$ and $\mathrm{NxT}$ total observations.

The data was statistically treated with Stata software using xtreg command for panel data approach. After Hausman test, using sigmamore (Note 5) option to test for choosing fixed or random effects we concluded for a model with fixed effects. Fixed effects explore the relationship between explanatory and outcome variable within a company. Each firm has its own individual characteristics that may or may not influence the predictor variables. When using fixed effects, we assume 
that something within the company may impact or bias the predictor or outcome variables and we need to control for this. This is the reason behind the assumption of the correlation between entity's error term and predictor variables. Fixed effects remove the effect of those time-invariant characteristics, so we can assess the net effect of the predictors on the outcome variable (Reyna, 2007).

We also test Cross sectional dependence with Breusch-Pagan LM test. According to Baltagi (2008), cross-sectional dependence is a problem in macro panels with long time series (over 20-30 years). Then we test for heteroskedasticiy that is available for the fixed- effects model using the command xttest3. Also, serial correlation was verified within the model using xtserial (Drukker, 2003) command. In order to correct the model for heteroskedasticiy and cross-sectional dependence this paper uses the Driscoll and Kraay (1998) method. Hoechle (2007) argues that xtscc program produces Driscoll and Kraay (1998) standard errors for linear panel models. Besides being heteroskedasticity consistent, these standard error estimates are robust to general forms of cross-sectional and temporal dependence. Driscoll and Kraay (1998) propose a nonparametric covariance matrix estimator that produces heteroskedasticity- and autocorrelation (serial correlation)-consistent standard errors that are robust to general forms of spatial and temporal dependence.

\section{Results and Discussion.}

In the Table 3 is displayed the main descriptive stats from the sample. Please note that the difference between the 1534 observations indicated in Methodology section and the ones presented in the table are due to missing values.

Table 3. Descriptive statistics

\begin{tabular}{lcrrrr}
\hline \multicolumn{1}{c}{ Variables } & Obs & \multicolumn{1}{c}{ Mean } & \multicolumn{1}{c}{ Std. Dev. } & \multicolumn{1}{c}{ Min } & \multicolumn{1}{c}{ Max } \\
\hline Company_Age_days & 1,534 & 25576.82 & 11593.42 & 749 & 55038 \\
PERatioBasic & 1,517 & 57.30042 & 438.6675 & -1350 & 14781.25 \\
researchoverassets & 1,532 & .0093002 & .010654 & -.0049897 & .075816 \\
payout & 1,324 & .3921441 & 1.344549 & -27.5 & 27.53846 \\
SellingGeneralAdministrativ & 1,533 & 1991 & 2003.336 & -2156 & 18025 \\
cashassets & 1,532 & .0733959 & .0714592 & -.0146843 & .5444807 \\
IssuancePurchaseOfEquitySh & 1,533 & -1345.774 & 3134.776 & -44270 & 3389 \\
debtPPP & 1,533 & 1.380589 & 3.06634 & 0 & 26.47126 \\
NetSalesOrRevenues & 1,533 & 10311.12 & 11120.65 & -9945.7 & 82989 \\
\hline
\end{tabular}

After running the model, we reach a test $(\mathrm{F})$ to see whether all the coefficients in the model are different than zero and conclude for the adequacy of the model. Furthermore, we find that 5 variables are significant for an alpha of $1 \%$, one variable significant at an alpha of 5\% and two variables significant at an alpha of $10 \%$ to explain firm age. Also, the square R shows the amount of variance of company age explained by the significant variables, $51 \%$. As expected, growth opportunities measured by market value related with earnings are important drivers to postpone life and consequently, age. However, this multiple, although significant, has a negative relation with age, denoting that the bigger gap between market cap and earnings is verified in early years of a company. If age evolves this growth opportunity predictor decreases. As firm ages, the price earnings ratio is lower as life cycle theories defend. Although firms in the growth stage of the life cycle may have insufficient resource base, these firms are promising, profitable, and have strong potential and less uncertainty about cash flow (Dickinson, 2011) and thus high PER in early stages.

Table 4. Model results estimation

\begin{tabular}{lll}
\hline Regression with Driscoll-Kraay standard errors & Number of obs & 1324 \\
\hline Method: Fixed-effects regression & Number of groups & 13 \\
Group variable (i): Company & F( 8,101) & 67.82 \\
maximum lag: 4 & Prob >F & 0.0000 \\
& within R-squared & 0.5159 \\
\hline
\end{tabular}


Table 4. Model results estimation (conti.)

\begin{tabular}{lllllll}
\hline Company_Age_days & Coef. & Std. Err. & $\mathbf{t}$ & P>t & [95\% Conf. & Interval] \\
\hline PERatioBasic & -.2384497 & .1046249 & -2.28 & 0.025 & -.4459973 & -.0309021 \\
researchoverassets & -23817.83 & 12872.62 & -1.85 & 0.067 & -49353.64 & 1717.991 \\
payout & 110.9387 & 56.1587 & 1.98 & 0.051 & -.4650968 & 222.3424 \\
SellingGeneralAdministrativ & .6412501 & .1436684 & 4.46 & 0.000 & .3562506 & .9262496 \\
cashassets & 13469.82 & 1541.011 & 8.74 & 0.000 & 10412.87 & 16526.77 \\
IssuancePurchaseOfEquitySh & -.1071869 & .0253054 & -4.24 & 0.000 & -.157386 & -.0569877 \\
debtPPP & 161.626 & 52.14519 & 3.10 & 0.003 & 58.18395 & 265.068 \\
NetSalesOrRevenues & .0948411 & .0165559 & 5.73 & 0.000 & .0619986 & .1276836 \\
cons & 22604.72 & 476.8149 & 47.41 & 0.000 & 21658.85 & 23550.59 \\
\hline
\end{tabular}

Age is positively related with $R \& D$. The presented results are consistent with the liability of newness, meaning that company investment in R\&D takes time to impact on financial performance, and for that can create opportunities through innovation to extend product life cycle or to create other products or services increasing the lifespan of a firm as supported by Yang and Aldrich (2017). Also, Rafiq et al. (2016) conclude that mature R\&D active firm earns more profit than a younger non-innovative firm. R\&D weigh in assets reflects research and innovation intensity and has a higher balance in early ages of a firm, whose explains the negative relation with age. As a company evolves in its life cycle and age, the weight of R\&D expenses is lower on total assets and this reflects the mature state of a firm. This is a concept of the outmost importance for the future and the ageing of a firm. The seed of R\&D given its time-shifted effect assures (increases the odds) the likelihood of a firm to reach higher longevity. Wöhrl (2009) suggests that different stages in the development of firms call for specific levels of R\&D intensity to sustain growth and profitability. Rafiq et al. (2016) conclude that a firm engaging in R\&D activities earns $4 \%$ to $11 \%$ higher sales and generates $4 \%$ to $13 \%$ more profits than firms that do not engage in R\&D activities.

Payout ratio indicates the level of remuneration to shareholders considering that the dividend can be over EPS (distribution of retained earnings), equal EPS or under (most usual case). The results indicate that high levels of payout ratio are a characteristic of higher firm age. Jang et al. (2016) finds that Low (high) payout ratios are associated with high (low) level of firm values. The same outcome was reached by Reis \& Augusto (2014a). We are studying the lifespan of a company and not his valuation, however, the relation of both the issues are important. High dividend policy is associated with older companies, in a mature state of the life cycle and with a strong financial status. Indirectly of course implies that the company has good EPS, good operating performance that allows to keep the stakeholders happy and willing to fund the company with equity ordinary, preference shares, mezzanine or senior debt. This ratio captures and brings trust to the company and implies extension of company life. Today, trust, confidence is a pertinent and important factor with firm success. Farre-Mensa et al. (2013), defend that none of the three traditional explanations (agency, signaling, and taxes) can account for secular changes in how payouts have been made over the past 30 years. They also state that repurchases have replaced dividends as the prime vehicle for corporate payouts. Other payout motivations, such as changes in compensation practices and management incentives, are better able to explain the observed variation in payout patterns over time than the traditional motivations. They conclude that most recent evidence suggests that additional understandings can be expanded from observing payout decisions as an essential part of a firm's larger financial ecosystem, and thus causing important implications for financing, investment, and risk management. That's why payout decisions could have a broader scope attaining results in avoiding share oscillation, giving stability to returns, assuring credibility, guaranteeing equity and debt finance, keeping lower agency costs, less pressure on board members, and contributing to extend company life. According to Bonaimé et al. (2014), payout flexibility offers operational hedging benefits when comparing to repurchases, avoiding risk management and protecting a firm's financial flexibility - the ability to avoid costly financial distress as well as underinvestment. They find that a more flexible distribution, favoring repurchases over dividends, is negatively related to financial hedging within a firm.

Selling, General and Administrative (S\&A) expenses are considered as a burden, as they are a fixed cost and jeopardize critical sales point. This item has a positive relation with age, showing that mature companies has more (S\&A) expenses. Nevertheless, in the opinion of the author this item shows the ability of the company to cope with 
legal, tax, compliance and other liabilities. A big company is subjected to several environmental attacks whether form SEC (Securities and exchange commission), tax authorities, claims from investors, clients and other stakeholders, with several potential focuses of litigation. An internal auditing, compliance, risk management and liability control, including outsource teams are needed to extend company life dealing with costs of context. S\&A expenses are related with age and with size as has been testified by Anderson et al. (2003) when they find, for a sample of 7,629 firms over 20 years, that selling, general, and administrative (SG\&A) costs increase on average $0.55 \%$ per $1 \%$ increase in sales but decrease only $0.35 \%$ per $1 \%$ decrease in sales.

Cash on assets being extremely significant (for an $\alpha=1 \%$ ), represents a safeguard for a company. Liquidity and availability of money (cash pile) enhances firm financial and economic strength acting as an extra collateral for investors, creditors, allowing investments, and M\&A operations assuring eventual growth and firm permanence in activity, in life. Harford et al. (2014), defend that firms mitigate refinancing risk by increasing their cash holdings and saving cash from cash flows. The maturity of firms' long-term debt has reduced noticeably, and this explains a large fraction of the increase in cash holdings over time, according the authors. This is consistent with the implication that cash reserves are particularly valuable for firms with refinancing risk.

Issuance or Purchase of own Equity Shares shows a negative influence on age, or issuance is a characteristic of younger companies, and reversely, share buybacks or repurchases are related with more mature, older companies. In fact older companies tent to maintain a stable and attractive remuneration to shareholders in order to maintain or to increase valuation and thus increasing lifespan. Akyol \& Foo (2013) state that undervaluation motive is a stronger signal than other repurchase motives. Although there's no evidence that repurchase is more tax efficient than dividends it is being used as an alternative and option for investors. More recently a new combination is used for bigger companies to reward investors- Santander bank pays dividends or, as a substitute, distribute new shares incorporated from retained earnings. Andriosopoulos \& Hoque (2013) find that size, cash dividends, and ownership concentration have a significant impact on share repurchase. A share repurchase guarantees market liquidity, but isn't as much attractive as dividends and new share distribution, however creates a constant demand and offer stabilizing the market and creating a long-term environment for companies.

Long term debt financing net property plant and equipment (NPPP) is positively correlated with age. A strong long-term financing and equity that could cover long term assets complies with the elementary rule of financial equilibrium. An older company gathers more financial experience, eventual less risk due to historic fulfilment and hence be more attractive to creditors. So, longer term for debt is more liable to occur for elder firms allowing companies the financial steadiness and contributing for company ageing. A good level of NPPP, although not indispensable, considering other intangible assets, cash flows, securitizations or others, works as a good collateral for creditors. Longer term debt can impose less overhang risk if asset volatility is higher in bad times (Diamond \& He, 2014). However Aivazian et al. (2005) show that a higher percentage of long-term debt in total debt significantly reduces investment for firms with high growth opportunities. The findings in this paper are testified by Ezeoha \& Botha (2012) showing that firms with higher collateral value are likely to face fewer constraints on borrowing and therefore have greater access to medium-term and long-term debts. They also state that during start-up and maturity stages, a firm's access to debt markets is significantly influenced by investments in assets that are acceptable to external creditors as collateral. The authors still suggest that debt financing policies could be more critical for firms in the start-up and maturity stages. Moon et al. (2015) also find support for the notion that preserving debt capacity in the form of higher tangibility (assets) reinforces the positive abnormal returns over and above the effect of a zero-leverage (Geske et al. 2016). Zhu (2013) indicates that leverage increasing firms tend to be more profitable and his finding is consistent with the fact that more profitable firms usually have easier access to debt markets.

Bigger companies, live longer. Size measured by net sales indicates the resilience against cycle movements and the capacity to face eventual adversity. Yasuda (2005) confirms this paper's conclusion that a firm's survivability rises with its size and age. Doğan (2013) indicates a positive relation between size and profitability of firms, although the age of the firms has been found in a negative relation with ROA. The empirical evidence suggests that the relationship between firm size and the likelihood of survival is shaped by technology and the stage of the industry life cycle (Agarwal \& Audretsch, 2001). Fort et al. (2013) state evidence that young businesses (that are typically small) display very different cyclical dynamics than small/older businesses. Young/small businesses are more sensitive to the cycle than older/larger businesses. Also Park et al. (2010) confirm that firm size and age have significant negative effects on firm growth and significant positive impacts on firm survival. We use net sales as a proxy for firm size and when compared with other metrics of firm size like assets, $\mathrm{n}^{\mathrm{o}}$ of employees and market capitalization, according to Dang et al. (2018) sales are more related to product market which is relevant to measure market share, endurance of the product and life cycle stage. 


\section{Conclusions}

This sample of blue ship companies and panel regressions with Driscoll-Kraay estimator shows that the most relevant factors to induce longevity are related with growth opportunities perspective and horizon, cash liquidity, profitability and shareholders remuneration whether from dividends or repurchases, capital structure, strong claims-compliance-liability structure department, innovation and firm size. Although presenting a negative relation with earnings, PER seems to be lower for mature companies, given possible growth opportunities for mature companies this is a vital ratio to keep in close attention since it can transmit to investors the potencies of profit for the future. So, constant search for value and new business must be a guidance to effective board members creating some constant dynamics and avoid the decline part of firm life cycle rejuvenating the company. A big pile of cash, characteristic of mature companies that presented previous growth, is a significant driver for extended life. In fact, financial solidity reflects itself on debt conditions, on the resilience of economic downturns, on stabilizing shareholders returns trough dividend or share buyback. Cash is a source of energy that can also allow M\&A operations, investments and face certain liabilities that companies are endangered during its operations.

Constant and attractive remuneration related with a profitability business gives to providers of funding, whether by equity, preference shares, mezzanine, senior or junior loans, a degree of confidence that can only be achieved by good track record experience. This allows a strong elasticity and good image, attracting investors and bringing new businesses. A good managed company also attracts new line of business through inventors that approach those companies to ask for help to develop their new products or services. This will also allow a company to choose a long-term capital structure giving to firm the balance for dealing with investments, acquisitions, remuneration, avoiding debt overhang. A profitable and continuous business is only achieved over a good R\&D intensity investment. This paper data shows that younger companies display a high R\&D intensity ratio than older companies, but this underlines the need to maintain a constant degree of innovation to create a wave of enduring growth assuring longevity. Claims, business liabilities, legal actions, full compliance needs (environmental, stock market, activity, etc.) are important downsides of being in the market. An older company must have a strong army to cope with costs of being large and older. This issues in addition of creating potential losses, damages image, brand and consequently the life of a company. A strong team capable of dealing and reduce the impact of those items in the company is of the outermost importance. Size attracts and endures life span. A big company has more willingness to stay in the market and has a bigger shield to cope with risks.

Our long-term panel of 33 years, studies the relevant factors explaining firm lifespan and can supply directions for strategies to be followed by professionals and academics to a big and broader scope of studies, to study longevity of companies, using company age as a dependent variable.

\section{References}

Agarwal, R., \& Audretsch, D. B. (2001). Does Entry Size Matter?. The Impact of the Life Cycle and Technology on Firm Survival. Journal of Industrial Economics, 49(1), 21-43. https://doi.org/10.1111/1467-6451.00136

Ahlstrom, D., Bruton, G. D., \& Yeh, K. S. (2008). Private firms in China: Building legitimacy in an emerging economy. Journal of World Business, 43(4), 385-399. https://doi.org/10.1016/j.jwb.2008.03.001

Ahlstrom, D., Young, M. N., Chan, E. S., \& Bruton, G. D. (2004). Facing constraints to growth?. Overseas Chinese entrepreneurs and traditional business practices in East Asia. Asia Pacific. Journal of Management, 21(3), 263-285. https://doi.org/10.1023/B:APJM.0000036463.20310.de

Aivazian, V. A., Ge, Y., \& Qiu, J. (2005). Debt maturity structure and firm investment. Financial Management, 34(4), 107-119. https://doi.org/10.1111/j.1755-053X.2005.tb00120.x

Akyol, A. C., \& Foo, C. C. (2013). Share Repurchase Reasons and the Market Reaction to Actual Share Repurchases: Evidence from Australia. International Review of Finance, 13(1), 1-37. https://doi.org/10.1111/j.1468-2443.2012.01159.x

Anderson, M. C., Banker, R. D., \& Janakiraman, S. N. (2003). Are Selling, General, and Administrative Costs "Sticky"?. Journal of Accounting Research, 41(1), 47-63. https://doi.org/10.1111/1475-679X.00095

Andriosopoulos, D., \& Hoque, H. (2013). The determinants of share repurchases in Europe. International Review of Financial Analysis, 27, 65-76. https://doi.org/10.1016/j.irfa.2012.12.003

Audretsch, D.B., \& Mahmood, T. (1994). Firm selection and industry evolution: the post-entry performance of new firms. J Evol Econ., 4(3), 243-260. https://doi.org/10.1007/BF01236371

Autio, E., Sapienza, H. J., \& Almeida, J. G. (2000). Effects of age at entry knowledge intensity, and. imitability on 
international growth. Academy of Management Journal, 43(5), 909-924. https://doi.org/10.2307/1556419

Baltagi, Badi H. (2008). Econometric Analysis of Panel Data. Wiley.

Barron, D. N., West, E., \& Hannan, M. T. (1994). A time to grow and a time to die: Growth and mortality of credit unions in New York City, 1914-1990. American Journal of Sociology, 100(100), 38-421. https://doi.org/10.1086/230541

Bonaimé, A. A., Hankins, K. W., \& Harford, J. (2014). Financial flexibility, risk management, and payout choice. Review of Financial Studies, 27(4), 1074-1101. https://doi.org/10.1093/rfs/hht045

Carr, J. C., Haggard, K. S., Hmieleski, K. M., \& Zahra, S. A. (2010). A study of the moderating. Effects of firm age at internationalization on firm survival and short-term growth. Strategic Entrepreneurship Journal, 4(2), 183-192. https://doi.org/10.1002/sej.90

Chen, Huafeng (2011). Firm life expectancy and the heterogeneity of the book-to-market effect. Journal of Financial Economics, 100(2011), 402-423. https://doi.org/10.1016/j.jfineco.2010.12.007

Chrisman, J. J., \& Patel, P. J. (2012). Variations in R\&D investments of family and nonfamily firms: Behavioral agency and myopic loss aversion perspectives. Academy of Management Journal, 55(4), 976-997. https://doi.org/10.5465/amj.2011.0211

Churchill, N. C., \& Lewis, V. L. (1983, May-June). The five stages of small business growth. Harvard Business Review, 30-50.

Coad, A., Segarra A., \& Teruel, M. (2013, March). Like milk or wine: does firm performance improve with age?. Struct. Chang. Econ. Dyn., 24, 173-189. https://doi.org/10.1016/j.strueco.2012.07.002

Coad, A. (2010). The exponential age distribution and the Pareto firm size distribution. J. Ind. Compet. Trade, 10(3), 389-395. https://doi.org/10.1007/s10842-010-0071-4

Coad, Alex, Rubæk J., Holm, Kraff, Jackie, \& Quatraro, Francesco. (2017). Firm age and performance. Journal of Evolucionary Economics, Setmber $9^{\text {th }}$. https://doi.org/10.1007/s00191-017-0532-6

Coad, Alex, Segarrac, Agustí, \& Teruel, Mercedes. (2016). Innovation and firm growth: Does firm age play a role?. Research Policy, 45(2016), 387-400. https://doi.org/10.1016/j.respol.2015.10.015

Cowling, M. (2006). Early stage survival and growth. In Parker S (Ed.), Handbook of entrepreneurship research: the life cycle of entrepreneurial ventures (pp. 477-504). Springer, Berlin. https://doi.org/10.1007/978-0-387-32313-8_16

Cyert, R., \& March, J. (1963). A behavioral theory of the firm. Englewood Cliffs, NJ: Prentice-Hall.

Dang, C., (Frank) Li, Z., \& Yang, C. (2018). Measuring firm size in empirical corporate finance. Journal of Banking \& Finance, 86, 159-176. https://doi.org/10.1016/j.jbankfin.2017.09.006

Desai, V. M. (2008). Constrained growth: How experience, legitimacy, and age influence risk taking in organizations. Organization Science, 19(4), 594-608. https://doi.org/10.1287/orsc.1070.0335

Diamond, D. W., \& He, Z. (2014). A theory of debt maturity: The long and short of debt overhang. Journal of Finance, 69(2), 719-762. https://doi.org/10.1111/jofi.12118

Dickinson, V. (2011). Cash flow patterns as a proxy for firm life cycle. The Accounting Review, 86(6), 1969-1994. https://doi.org/10.2308/accr-10130

Doğan, M. (2013). Does Firm Size Affect The Firm Profitability? Evidence from Turkey. Research Journal of Finance and Accounting, 4(4), 53-60.

Driscoll, J., \& A. C. Kraay. (1998). Consistent covariance matrix estimation with spatially dependent data. Review of Economics and Statistics, 80, 549-560. https://doi.org/10.1162/003465398557825

Drukker, David M. (2003). Testing for serial correlation in linear panel-data models. The Stata Journal, 3(2), 168-177.

Ezeoha, A., \& Botha, F. (2012). Firm age, collateral value, and access to debt financing in an emerging economy: evidence from South Africa. South African Journal of Economic and Management Sciences, 15(1), 72-93. Retrieved

from http://sajems.org/index.php/sajems/article/view/138\%5Cnhttp://sajems.org/index.php/sajems/article/viewArticle $/ 138$ 
Farre-Mensa, J., Michaely, R., \& Schmalz, M. (2013). Payout Policy. Annual Review of Financial Economics, 6(1), 75-134. https://doi.org/10.1146/annurev-financial-110613-034259

Ferreira, M. A., \& Laux, P. A. (2007). Corporate governance, idiosyncratic risk, and information flow. Journal of Finance, 62(2), 951-989. https://doi.org/10.1111/j.1540-6261.2007.01228.x

Fink, J., Fink, K., Grullon, G., \& Weston, J. (2010). What drove the increase in idiosyncratic volatility during the internet boom?. Journal of Financial and Quantitative Analysis, 45(5), 1253-1278. https://doi.org/10.1017/S0022109010000487

Fort, T. C., Haltiwanger, J., Jarmin, R. S., \& Miranda, J. (2013). How Firms Respond to Business Cycles: The Role of Firm Age and Firm Size. IMF Economic Review, 61(3), 520-559. https://doi.org/10.1057/imfer.2013.15

Gaspar, J.M., \& Massa, M. (2006). Idiosyncratic volatility and product market competition. The Journal of Business, 79(6), 3125-3152. https://doi.org/10.1086/505251

Geske, R., Subrahmanyam, A., \& Zhou, Y. (2016). Capital structure effects on the prices of equity call options. Journal of Financial Economics, 121(2). https://doi.org/10.1016/j.jfineco.2016.03.009

Haltiwanger, J., Jarmin, R., \& Miranda, J. (2013) Who creates jobs?. Small vs large vs young. Rev Econ Stat, 95(2), 347-361. https://doi.org/10.1162/REST_a_00288

Hannan, M.T., \& Freeman, J. (1984). Structural inertia and organizational change?. American Sociological Review, 49(2), 149-164. https://doi.org/10.2307/2095567

Harford, J., Klasa, S., \& Maxwell, W. F. (2014). Refinancing risk and cash holdings. Journal of Finance, 69(3), 975-1012. https://doi.org/10.1111/jofi.12133

Hasan, Mostafa Monzur, Habib, \& Ahsan (2017). Firm life cycle and idiosyncratic volatility. International Review of Financial Analysis, 50, 164-175. https://doi.org/10.1016/j.irfa.2017.01.003

Hoechle, Daniel. (2007). Robust standard errors for panel regressions with cross-sectional dependence. The Stata Journal, 7(3), 281-312.

Jang, Bong Gyu, Rhee, Yuna, \& Yoon, Ji Hee. (2016). Business cycle and credit risk modeling with jump risks. Journal of Empirical Finance, 39(4), 15-36. https://doi.org/10.1016/j.jempfin.2016.08.001

Kazanjian, R. K. (1988). Relation of dominant problems to stages of growth in technology-based new ventures. Academy of Management Journal, 31, 257-279. https://doi.org/10.2307/256548

Levinthal, D. A., \& March, J. G. (1993). The myopia of learning. Strategic Management Journal, 14(S2), 95-112. https://doi.org/10.1002/smj.4250141009

Loderer, C., Stulz, R., \& Waelchli, U. (2017). Firm rigidities and the decline in growth opportunities. Manag Sci, forthcoming. https://doi.org/10.1287/mnsc.2016.2478

Luo, X., \& Bhattacharya, C. B. (2009). The debate over doing good: Corporate social performance, strategic marketing levers, and firm-idiosyncratic risk. Journal of Marketing, 73(6), 198-213. https://doi.org/10.1509/jmkg.73.6.198

Moon, G., Lee, H., \& Waggle, D. (2015). The effect of debt capacity on the long-term stock returns of debt-free firms. Applied Economics, 47(4), 333-345. https://doi.org/10.1080/00036846.2014.959655

Park, Y., Shin, J., \& Kim, T. (2010). Firm size, age, industrial networking, and growth: A case of the Korean manufacturing industry. Small Business Economics, 35(2), 153-168. https://doi.org/10.1007/s11187-009-9177-7

Rafiq, Shuddhasattwa, Salimb, Ruhul, \& Smyth, Russell. (2016). The moderating role of firm age in the relationship between R\&D expenditure and financial performance: Evidence from Chinese and US mining firms. Economic Modelling, 56(2016), 122-132. https://doi.org/10.1016/j.econmod.2016.04.003

Reis, Pedro, M. Nogueira, \& Augusto, Mário G. (2013). Determinants of Terminal Value in the Evaluation of Companies: A Panel Data Approach to the Context of European Companies. International Research Journal of Finance and Economics, 117(2013), 118-138.

Reis, Pedro, M. Nogueira, \& Augusto, Mário G. (2014a, July/August). Determinants Of Firm Terminal Value: The Perspective Of North American And European Financial Analysts. International Business \& Economics Research Journal, 13(4), 1-16.

Reis, Pedro, M. Nogueira, \& Augusto, Mário G. (2014b). What Is a Firm’s Life Expectancy? Empirical Evidence in 
the Context of Portuguese Companies. Journal of Business Valuation and Economic Loss Analysis, 10(1), 45-75. https://doi.org/10.1515/jbvela-2014-0003

Reyna, Oscar Torres. (2007). Panel Data Analysis Fixed and Random Effects using Stata. Retrieved from http://dss.princeton.edu/training/

Stinchcombe, A. L. (1965). Organizations and social structure. Handbook of organizations, 44, 142-193.

Watson, J. (2012). Networking: gender differences and the association with firm performance. International Small Business Journal, 30(5), 536-558. https://doi.org/10.1177/0266242610384888

Wöhrl, R., Hüsig, S., \& Dowling, M. (2009). The interaction of R\&D intensity and firm age: Empirical evidence from technology-based growth companies in the German "Neuer Markt". Journal of High Technology Management Research, 20(2009), 19-30. https://doi.org/10.1016/j.hitech.2009.02.006

Xie, Qunyong. (2017). Firm age, marketization, and entry mode choices of emerging economy firms: Evidence from listed firms in China. Journal of World Business, 52(2017), 372-385. https://doi.org/10.1016/j.jwb.2017.01.001

Yasuda, T. (2005). Firm growth, size, age and behavior in Japanese manufacturing. Small Business Economics, 24(1), 1-15. https://doi.org/10.1007/s11187-005-7568-y

Zhu, Y. (2013). Determinants of long-term debt issuing decisions: An alternative approach. Australian Journal of Management, 38(2), 429-439. https://doi.org/10.1177/0312896212461640

\section{Notes}

Note 1. Reuters 2017 sample of listed North, South American and European companies

Note 2. http://www.bbc.com/news/business-16611040, consulted in October 17, 2017 and according to the Guinness Book of World Records.

Note 3. http://www.atlasobscura.com/articles/the-world-s-oldest-companies, consulted in October 17th, 2017.

Note 4. Company age, PER, Price to Book sales, Price to Book ratio, research expenses, Sales, Taxes, Equity, Dividends per share, EPS, Gross profit, Selling and general expenses, Cash, Capex, Operating cash flow, Issue or purchase own shares, average shares, Long term debt, Property, plant and equipment, Total current liabilities

Note 5. According to Stata Hausman specification test option Sigmamore description, Sigmamore specifies that "the covariance matrices be based on the estimated disturbance variance from the efficient estimator. This option provides a proper estimate of the contrast variance for so-called tests of exogeneity and overidentification in instrumental-variables regression." 